\title{
The possible cytogenecity and mutagenicity effects of Allium sativum as a natural fungi/ pesticide on faba bean plant
}

Received: 26 October, 2020

Accepted: 21 November, 2020

Published: 24 November, 2020

${ }^{*}$ Corresponding author: Rania T Ali, Department of Genetics \&Cytology, National Research Center, Egypt, E-mail: raniatawfick@hotmail.com

Keywords: Garlic; Allium sativum; Mitosis; Cytotoxicity; Proteins profile; SDS-PAGE

https://www.peertechz.com

\section{Check for updates}

\author{
Samira A Osman, Rania T Ali* and Haiba AAA
}

Department of Genetics \& Cytology, National Research Center, Egypt

\begin{abstract}
Allium sativum (garlic) is one of the most famous plant rich in Sulphur products which are so beneficial in bio-gardening and agriculture if applied in right ratios as natural fertilizer to the soil poor in organic matter (under $2 \%$ ) or applied as natural fungicide \&pesticide. It like many other important folk plants needs further investigations and revising for its products' cytogenecity and mutagenicity. This study was designed to highlight the mode of action of fresh garlic water extract against two other garlic products (powder and tablets) dissolved in water on faba bean plant, as an ideal model system for both cytogenetic and biochemical investigations. Tomix tablets in water (two and three tablets/L), garlic powder ( 400 and $600 \mathrm{mg} / \mathrm{L}$ ) and aqueous extract of smashed fresh garlic cloves ( 4500 and $7110 \mathrm{mg} / \mathrm{L}$ ) were examined for their effect on plant mitosis and protein profile after 24 and $48 \mathrm{hr}$ of treatments. The obtained results showed that; treatment with each form of the three tested garlic products induced concentration dependent reduction in the mitotic index, and affected notable change in the mitotic phase' frequencies. Its effect on chromatin material is much greater than its effect on spindle formation or chromosomes mobility in cytoplasm. It also affected the proteins profile of the treated seedlings using SDS-PAGE.
\end{abstract}

Conclusion: Treatment with fresh garlic and with garlic powder shows concentration dependent cytogenecity and mutagenecity. Prolongation of treatment time to $48 \mathrm{hr}$ increases the clastogenecity risk. Recommendation: the usage of fresh Garlic extract as a fungi/ pesticide in agriculture should be with caution, as it show some mutagenicity and cytogenicity.

\section{Introduction}

Some of plants' derivatives (ashes, extracts, oil, powder and pasts) have been admitted as effective natural defense system to other plants against biological pests and pathogens in an eco-friendly way.

These derivatives can keep the environment cleaner, less hazardous and healthier if compared with other chemically synthesized pesticides, herbicides or fungicides; which found to be a real threat to the air, soil, irrigation canals and wells as they are not easy to be degradable. Moreover, the extensive usage of these chemicals found to enhance the pest's resistance year over year (ISU Extension and Outreach and North Central IPM Center for financial support; guide flyer) and may cause a serious deterioration in plant and crop quality. Thus, inspire the researchers to seek for natural active pesticidal and or fungicidal (plant products\& preparations) and re-consider this natural gift and revise it on many levels to declare its effectiveness and safety.

The cytogenetic level and gene expression level come to the front of those levels of revising. For example; natural pesticides such as Sorghum bicolor seedling water extract and petroleum ether extract of Nasturtium officinale seedlings' extract which can control the cotton leaf warm and the seeds powder of lupinus termis and black cumin which can protect the stored seeds from bruchids' attack; were all studied and revised for their possible cyto-genecity and mutagenicity on Vica faba plant $[1,2]$. Some of plants' essential oils are already marketed as fungicides for bio-gardening such as. "E-Rase" $\mathrm{T}^{\mathrm{TM}}$ " from jojoba oil, "Sporan ${ }^{\mathrm{TM}}$ " from rosemary oil, "Promax ${ }^{\mathrm{TM}}$ " from thyme oil, "Trilogy" ${ }^{\mathrm{TM}}$ " from neem oil and " $\mathrm{GC}-3^{\mathrm{TM}}$ " being a mixture of cottonseed oil and garlic Allium sativum [3].

Among the promising natural product is Garlic (Allium sativum) which known by the therapeutic effect of its derivatives 
in agriculture as it contains an abundance of chemical compounds such as organophosphorus and Allicin compounds that have been shown to possess beneficial effects to protect against several plant pathogens [4].

Garlic (Allium sativum L., order Asparagales, Family Liliaceae) is a widely distributed plant in our region; it is herbaceous plant with height of $20-40 \mathrm{~cm}$, a bulb of strong odor and pungent taste. It is one of the most important multi purposes used plant.

The active ingredient Allicin (allyl 2-propenethiosulfinate or diallyl thiosulfinate) is considered as a defense molecule and the principal bioactive compound present in the aqueous extract of garlic or raw garlic homogenate. When garlic is chopped or crushed, allicin is rived from alliin by alliinase enzyme (a CS-lyase, E.C. 4.4.1.4) [5].

Allicin in fresh garlic has an antibacterial effect on grampositive antibacterial and gram-negative bacteria [6], also an anti-fungal activity when applied to seeds before planting $[7,8]$ and can be used as natural pesticide controls nematodes in ground nuts, flower thrips (WFT) in strawberry, mildews in cucumber, tomato leaf miner, leaf blotch in cereals [9]. Allicin is suggested to have toxic effect as it is readily membrane permeable [10], and easily enters cells and reacts with cellular thiols such as glutathione [11] or cysteine residues in proteins [12]. As a consequence, enzymes with accessible reactive cysteines can be affected in their function [13].

So based on this context, garlic is considered as a very important plant with great beneficial rule on many other plants' protection against pathogens and pests. It may contribute to the development of natural products for the agricultural and other industrial uses as crud past, extract, it may be dried into powder or it may be used as building blocks' necessary to synthesize more complexed form such as medicinal tablets.

Study the mitotic division and phases index and frequency can give a clear image about the chromosomal behavior, segregation and transition of the genetic materials in-between the daughter cells in growing plants. Examine the bioactive natural products on model system meristem's cells reflect its mode of action on the mitotic apparatus [14].

Also, protein profiling of seedlings' total protein of model plant under treatment with examined material refers to the condition of gene expression into proteins.

The aim of this research is to visualize the cytogenetic and biochemical (SDS-PAGE) effects of Allium sativum (garlic) in three different forms (mashed fresh cloves, garlic powder and medicinal tablets) dissolved in water on Vicia faba L. (Giza 716 Egyptian cultivar) as plant model system.

\section{Materials \&methods}

The designed experiment was carried out on bench top in genetics and cytology lab, NRC, Egypt.

\section{I- Plant \& experimental materials}

The Vicia faba $(2 \mathrm{n}=12)($ Var. Giza 716$)$; used for all the conducted experiments, were obtained from the Crop Research Institute, ARC, Giza, Egypt. And then germinated on filter paper rolls in a large beaker with $3 \mathrm{~cm}$ height tap water at the bottom and divided into two groups for two designed experiments.

Tomix tablets (a natural medicinal preparation depends on garlic as building block) were purchased from pharmacy under commercial name "Tomix". The used doses are 2 \&3 tablets/ litter , Garlic powder (an organic food additive) was purchased from a grand store of foods under commercial name "isis", the used concentrations were $400 \& 600 \mathrm{mg} / \mathrm{L}$ which are calculated to be equivalent to the garlic ingredient in Tomix tablets and Garlic fresh raw (fresh aqueous extracts) were prepared after [6] in the lab as following: two weighs (two cloves $~ 4.5 \mathrm{gm} \&$ three cloves $\sim 7.11 \mathrm{gm}$ ) of garlic were crushed and smashed into fresh paste in clean mortar and then dissolved in $1 \mathrm{~L}$-as it is the best way to extract allicin from garlic.

\section{II- Treatment with the tested materials}

Experiment for cytological studies: About $2 \mathrm{~cm}$ length main roots of Vicia faba were treated for $24 \& 48 \mathrm{hrs}$ with the experimented materials for each concentration at room temperature. Treated roots were then fixed with Carnoy's fixative for $24 \mathrm{hr}$ before preservation in $70 \%$ alcohol. Slides were prepared for cytogenetic investigation [15]. Effects of examined chemical treatments and control on different chromosome plates were observed under Olympus light microscope. To determine the effect on mitotic index, 2500-3000 cells were scored in control group and in each treated sample.

Mitotic indexes and Percentages of cells showing chromosomal abnormalities and type of abnormality were recorded at the appropriate mitotic stages. Mitotic index were calculated by this formula:

$$
\text { Mitotic index }=\frac{\text { Number of dividing cells }}{\text { Total number of cells observed }} \times 100
$$

Experiment for protein electrophoresis group: After the seeds were germinated and grow to root, shoot and leaves whole seedling plant of Vicia faba were treated for $24 \& 48 \mathrm{hrs}$ with each of the experimented materials in two concentrations at room temperature.

Total proteins were extracted from the treated plant's leaves to perform sodium dodecyl sulfate-polyacrylamide gel electrophoresis (SDS-PAGE) according to the method of Laemmli [16] and as described in Tsugama, et al. [17]. By grinding $1 \mathrm{~g}$ of leaves and mixed with $1 \mathrm{ml}$ of extraction buffer in eppendorf tube and left in refrigerator overnight, then vortexed for 15 seconds and centrifuged at $12,000 \mathrm{rpm}$ at $4{ }^{\circ} \mathrm{C}$ for $20 \mathrm{~min}$. The supernatants containing total proteins were transferred to new eppendorf tubes and kept at deep-freeze until use for electrophoretic analysis. The marker of the used protein is BLUltra Prestained Protein Ladder (GeneDirex, Cat No. PMoo10500 ). In this method, $10 \%$ protein separating gel were used. Protein fractionations were performed on vertical slab gel (19.8 $\mathrm{cm} \times 26.8 \mathrm{~cm} \times 0.2 \mathrm{~cm}$ ) using the electrophoresis apparatus manufactured by Cleaver, UK. The images were captured by 
digital camera (Sony, made in Japan) and transferred directly to the computer and then the protein bands were analyzed by Total Lab program to find out the molecular weight of each band and that to find the effect of each treatment on gene expression of different genes responsible for the formation of proteins in faba beans.

\section{Results}

The data shown in (Tables 1,2) revealed that: $24 \mathrm{hr}$ treatment, each form of the three tested garlic product induced concentration dependent reduction in the mitotic index at root tip meristems of Vicia faba relative to the control, it also reveals that, the aqueous extract of garlic fresh cloves followed by the garlic powder in their lower concentrations score the highest mitotic index among the tested materials; this was reversed by increasing their concentration as they score the lower mitotic index which means; this form of garlic product at the higher concentration are the most destructive as they have the higher cytotoxic effect (Table 1).

It worth to mention that, although the cytotoxic effect was prolonged by expanding the exposure time of treatment to $48 \mathrm{hr}$, there was a notable improvement in the mitotic indexes recorded after the higher concentration of Garlic in the tested forms (3cruched Tomix tablets $8.03 \%$, 600mg Garlic powder $6.3 \%$ ) and nearly with no effect on mitotic index after 7.11gm/ L Garlic cloves (Table 2).

Garlic products affected notable change in the frequency of mitotic phases (Figure 1), mostly at prophase stage, as all forms prolong the prophase stages relative to control. As illustrated, $24 \mathrm{hr}$ treatment with $(4.5 \mathrm{gm} / \mathrm{L}$ of cloves aqueous extract showed the biggest effect on prophase stage $53.38 \%$ followed by the $600 \mathrm{mg} /$ liter of garlic powder $45.45 \%$. on the other hand treatment with three tomix tablets induced the highest effect on metaphase frequencies reaches $45.21 \%$ on response of anatelophase duration which was $15.75 \%$. Regarding the anatelophases garlic products in the three tested form alter the ana-telophases by lowering its index; except after the 400mg/ liter of garlic powder as it scored higher percentage if compared with control. Regarding the effect on both prophaeses and metaphases, $24 \mathrm{hr}$ treatment with three tablets of tomix induce the highest effect on prophase and metaphase frequencies reaches $39.04 \& 45.21 \%$ on response of ana-telophase duration which was $15.75 \%$ followed by treatment with $4.5 \mathrm{gm} / \mathrm{L}$ of garlic cloves induce the highest effect on prophase and metaphase frequencies reaches $53.38,21.43 \%$ on response of ana-telophase duration which was $25.19 \%$ as shown in Tables 1,2 and Figure 1.

Table 1: Mitotic index, percentages of abnormal mitosis and abnormality in each mitotic phase in Vicia faba root- tip meristems, after $24 \& 48$ hrs of treatment with extracts of three different Garlic form.

\begin{tabular}{|c|c|c|c|c|c|c|c|}
\hline Treatment & Concentration & Time for treatment & $\mathrm{MI} \pm \mathrm{SE}$ & $\begin{array}{c}\% \text { abn. } \\
\text { Mitoses + S.E. }\end{array}$ & $\begin{array}{l}\text { Prophase } \\
\% \text { abn. }\end{array}$ & $\begin{array}{c}\text { Metaphase } \\
\text { \%abn. }\end{array}$ & $\begin{array}{c}\text { Ana-telophase } \\
\text { \%abn. }\end{array}$ \\
\hline \multirow{4}{*}{ Tomix tablets } & \multirow{2}{*}{2 tablets } & $24 \mathrm{hr}$. & $6.3 \pm 1.00$ & $29.07 \pm 2.2$ & 3.03 & 90.30 & 25.30 \\
\hline & & $48 \mathrm{hr}$. & $4.2 \pm 0.12$ & $34.78 \pm 6.41$ & 0.00 & 65.38 & 39.19 \\
\hline & \multirow{2}{*}{3 tablets } & $24 \mathrm{hr}$. & $4.17 \pm 1.26$ & $37.8 \pm 1.9$ & 3.51 & 83.30 & 30.40 \\
\hline & & $48 \mathrm{hr}$. & $8.03 \pm 0.29$ & $37.86 \pm 2.1$ & 10.84 & 76.74 & 23.60 \\
\hline \multirow{4}{*}{ Garlic powder } & \multirow{2}{*}{$400 \mathrm{mg}$} & $24 \mathrm{hr}$. & $9.63 \pm 0.15$ & $26.35 \pm 1.5$ & 4.80 & 77.40 & 8.49 \\
\hline & & $48 \mathrm{hr}$. & $4.3 \pm 1.07$ & $46.6 \pm 7.1$ & 12.82 & 87.50 & 51.78 \\
\hline & \multirow{2}{*}{$600 \mathrm{mg}$} & $24 \mathrm{hr}$. & $3.6 \pm 0.56$ & $24.7 \pm 3.7$ & 12.00 & 72.70 & 30.60 \\
\hline & & $48 \mathrm{hr}$. & $6.3 \pm 0.10$ & $39.87 \pm 4.3$ & 17.24 & 64.28 & 75.68 \\
\hline \multirow{4}{*}{ Garlic fresh cloves } & \multirow{2}{*}{$4.5 \mathrm{gm} / \mathrm{L}$} & $24 \mathrm{hr}$. & $10.23 \pm 1.42$ & $23.56 \pm 0.6$ & 7.04 & 43.90 & 43.28 \\
\hline & & $48 \mathrm{hr}$. & $5.84 \pm 0.60$ & $31.03 \pm 2.5$ & 6.30 & 68.80 & 40.90 \\
\hline & \multirow{2}{*}{$7.11 \mathrm{gm} / \mathrm{L}$} & $24 \mathrm{hr}$. & $2.03 \pm 0.52$ & $35.42 \pm 2.2$ & 18.18 & 60.00 & 53.57 \\
\hline & & $48 \mathrm{hr}$. & $5.1 \pm 0.50$ & $23.49 \pm 1.8$ & 5.41 & 62.50 & 28.78 \\
\hline \multirow{2}{*}{\multicolumn{2}{|c|}{ control }} & $24 \mathrm{hr}$. & $11.2 \pm 1.64$ & $6.18 \pm 0.8$ & 2.63 & 7.14 & 6.34 \\
\hline & & $48 \mathrm{hr}$. & $9.15 \pm 1.7$ & $8.26 \pm 0.96$ & 3.90 & 10.80 & 10.20 \\
\hline
\end{tabular}

Table 2: Percentages of each abnormal type / scored mitosis number in Vicia faba root-tip meristems, after $24 \& 48 \mathrm{hr}$ of treatment with three different garlic forms.

\begin{tabular}{|c|c|c|c|c|c|c|c|c|c|c|c|c|c|}
\hline \multirow{3}{*}{ Treatment } & \multirow{3}{*}{ Concentration } & \multirow{3}{*}{ Treat. time } & \multicolumn{11}{|c|}{$\%$ Different types of abnormal mitoses/scored number } \\
\hline & & & \multicolumn{3}{|c|}{ Chromat. mater. Liquefac. abn. } & \multicolumn{5}{|c|}{ Chromosomal kinetic abnormality } & \multicolumn{2}{|c|}{ Chrom. structural aberr. } & \multirow[b]{2}{*}{ Micro-nu. } \\
\hline & & & Stic. & Sti.br. & Sum. & Dist. & Clump. & Lag. & Pro-meta & Sum. & Frag.\&break. & Sum. & \\
\hline \multirow{4}{*}{ Tomix tablets } & \multirow{2}{*}{2 tablets } & $24 \mathrm{hr}$ & 16.36 & 0.00 & 16.36 & 6.66 & 0.00 & 0.00 & 6.84 & 13.5 & 0.60 & 0.60 & 0.00 \\
\hline & & $48 \mathrm{hr}$ & 34.13 & 0.79 & 34.92 & 0.79 & 0.00 & 0.0 & 0.79 & 1.58 & 0.00 & 0.00 & 0.00 \\
\hline & \multirow{2}{*}{3 tablets } & $24 \mathrm{hr}$ & 10.90 & 0.68 & 11.58 & 24.65 & 0.00 & 3.4 & 3.42 & 31.5 & 0.68 & 0.68 & 0.00 \\
\hline & & $48 \mathrm{hr}$ & 29.87 & 0.00 & 29.87 & 7.05 & 0.83 & 0.0 & 0.41 & 8.29 & 0.00 & 0.00 & 1.59 \\
\hline \multirow{4}{*}{ Garlic powder } & \multirow{2}{*}{$400 \mathrm{mg}$} & $24 \mathrm{hr}$ & 15.90 & 0 & 15.90 & 0.43 & 0.69 & 2.4 & 0.86 & 4.38 & 0.00 & 0.00 & 2.40 \\
\hline & & $48 \mathrm{hr}$ & 37.82 & 0.00 & 37.82 & 4.2 & 0.00 & 0.00 & 4.2 & 8.4 & 0.00 & 0.00 & 1.68 \\
\hline & \multirow{2}{*}{$600 \mathrm{mg}$} & $24 \mathrm{hr}$ & 18.10 & 0 & 18.10 & 5.17 & 0.86 & 0 & 0.86 & 6.89 & 0.00 & 0.00 & 0.86 \\
\hline & & $48 \mathrm{hr}$ & 34.92 & 0.00 & 34.92 & 4.76 & 0.00 & 0.00 & 0.00 & 4.76 & 0.00 & 0.00 & 1.58 \\
\hline \multirow{4}{*}{ Garlic fresh cloves } & \multirow{2}{*}{$4.5 \mathrm{gm} / \mathrm{L}$} & $24 \mathrm{hr}$ & 13.71 & 0.88 & 14.59 & 8.40 & 0.88 & 1.3 & 0.88 & 10.58 & 0.00 & 0.00 & 1.30 \\
\hline & & $48 \mathrm{hr}$ & 21.92 & 0.00 & 21.92 & 2.74 & 0.69 & 0.69 & 2.05 & 6.17 & 0.69 & 0.69 & 5.48 \\
\hline & \multirow{2}{*}{$7.11 \mathrm{gm} / \mathrm{L}$} & $24 \mathrm{hr}$ & 27.86 & 3.2 & 31.06 & 6.50 & 0.00 & 0.0 & 0.00 & 6.50 & 0.00 & 0.00 & 0.00 \\
\hline & & $48 \mathrm{hr}$ & 18.90 & 1.22 & 20.12 & 1.22 & 1.22 & 0.00 & 0.00 & 2.44 & 0.61 & 0.61 & 3.66 \\
\hline \multirow{2}{*}{\multicolumn{2}{|c|}{ control }} & $24 \mathrm{hr}$ & 2.9 & 0.29 & 3.19 & 1.48 & 0.00 & 0.00 & 0.00 & 1.48 & 0.59 & 0.59 & 0.00 \\
\hline & & $48 \mathrm{hr}$ & 4.36 & 0.00 & 4.36 & 2.54 & 0.363 & 0.00 & 0.00 & 2.90 & 0.00 & 0.00 & 0.36 \\
\hline & & & & & & & & & & & & & 026 \\
\hline
\end{tabular}

Citation: Osman SA, Ali RT, Haiba AAA (2020) The possible cytogenecity and mutagenicity effects of Allium sativum as a natural fungi/ pesticide on faba bean plant 


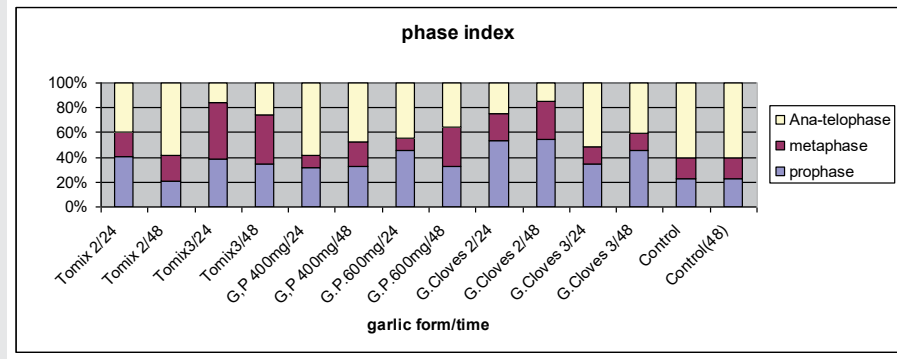

Figure 1: Phase index (PI) of Vicia faba root tip meristems after $24 \& 28 \mathrm{hr}$ treatment with the three different garlic products in different concentrations.

This was reversed after expanding the time of exposure to $48 \mathrm{hr} ; 4.5 \mathrm{gm} / \mathrm{L}$ of fresh cloves treatment had the highest effect on mitotic phases duration as it prolonged the prophase \& metaphase frequencies by $54.11 \& 30.82 \%$ on response of anatelophase duration $15.06 \%$. In the same track was the three tomix tablets induces the second highest effect on prophase and metaphase frequencies reaches $39.04,45.21 \%$ on response of ana-telophase duration which was $29.87 \%$.

$24 \mathrm{hr}$ of $400 \mathrm{mg}$ garlic powder affected the mitotic phases frequency but in different way of action, as it scored the highest Ana-telophase duration $66.23 \%$ (even if compared with control $60.9 \%$ ) on response of metaphase duration $10.73 \%$.

All concentration treatments of each Garlic forms inducing highly significant, increasing percentages of abnormal dividing cell of Vicia faba root meristems as shown in Table 3. The chromosomal aberrations were found to be concentration and time dependent most of the time except after treatment with $7.11 \mathrm{gm} / \mathrm{L}$ of Garlic cloves for $48 \mathrm{hr}$ as it induced lower percentage than expected.

Worth to mention that although $24 \mathrm{hr}$ treatment with Garlic powder induce lower percentages of abnormal mitosis reaches $26.35 \%$ after $400 \mathrm{mg}$ and scored $24.7 \%$ after $600 \mathrm{mg}$ concentration, the $48 \mathrm{hr}$ treatment with $400 \mathrm{mg}$ of Garlic powder was the most destructive, since it induced the higher percentages of abnormal mitoses reaches $46.6 \%$ followed by treatment with $600 \mathrm{mg}$ of Garlic powder form by $39.87 \%$.

All studied Garlic forms induced chromosomes abnormalities which mainly are of chromatin material liquefaction type such as sticky chromosomes and sticky bridges as shown in Table 2 and Figured 2,4,7 and 8 followed by Chromosomal kinetic abnormality type such as pro-metaphase (Figures 3,4 ), disturbances in very low percentages (Figures 6,8) and clumped chromosomes (Figures 9) followed by chromosomal structural aberrations in a very few percentages (Figure 5).

After $24 \mathrm{hr}$ treatment; higher concentration of Garlic fresh gloves aqueous extract scored the higher effect of liquefaction on chromosome material by the time three tablets of tomix showed the least liquefaction effect on chromatin material. By expanding the time of treatment to $48 \mathrm{hr}, 400 \mathrm{mg}$ followed by 60omg of Garlic powder showed the higher liquefaction effect on chromatin material by the time two tablets of tomix had the major kinetic effect.
Data revealed that $24 \mathrm{hr}$ treatment with Garlic fresh raw \& Garlic powder did not show any effect on chromosomes structure; despite of the low percentage of structural aberrations were scored after control (untreated faba plants) and after treatment with Tomix in its two concentrations. This was reversed after expanding the time of treatment to $48 \mathrm{hr}$ as the structure aberration was only noticed after treatment with Garlic fresh raw aqueous extract in its two concentrations. Regarding the micronucleus which comes as a result of structural aberration as real indicator for clastogenecity; data revealed that prolongation the time of treatment increase the risk of obtaining micronucleus; lower concentration of fresh garlic scored the higher clastogenecity $5.48 \%$ but this percentage was lowered by increasing the concentration to $3.66 \%$.

On the bio-chemical investigation level, the total protein electrophoresis of treated Vicia faba seedling showed the effect of different garlic forms on the gene expression (Figure 10).

The resulted effects varied from appearance of some new bands to disappearance of other bands. The total number of bands in the control (untreated plants) was 24 bands ranging from 270 to $12 \mathrm{KDa}$. The lowest number of recorded bands was 21 after treatment with $7.11 \mathrm{~g} / \mathrm{L}$ of fresh cloves for $24 \mathrm{hrs}$, while the highest bands number was 30 recorded after treatment with $7.11 \mathrm{~g} / \mathrm{L}$ of fresh cloves for $48 \mathrm{hrs}$ and treatment with two crushed tomix tablets for $24 \mathrm{hrs}$. There were a thirteen common protein bands (monomorphic bands ) showed at Mw 180, 130, $70,51,42,40,36,27,24,22,20,19$ and $15 \mathrm{KDa}$. Regarding the common effect within the two concentrations of each garlic form; protein analysis showed that: the $24 \mathrm{hrs}$ treatment with garlic fresh cloves recorded a common disappearance of protein bands at higher molecular weight $108,65 \mathrm{KDa}$. and a common appearance of new bands at lower molecular weight 23, $12 \mathrm{KDa}$, prolongation of treatment time to $48 \mathrm{hrs}$ treatment with fresh cloves showed protein band disappearance at $17 \mathrm{KDa}$. and bands appearance at 28, 23 \&12 KDa.

Treatment with crushed tomix tablets for 24 \& $48 \mathrm{hrs}$ recorded a common disappearance of protein bands at 195 , 95KDa and common appearance of new bands at 77, 28, 23 \&12 KDa.

Treatment with garlic powder in the two concentrations for $24 \mathrm{hrs}$ recorded common band disappearance at $56 \& 49$ $\mathrm{KDa}$ and common band appearance at molecular weight 270 , $150,140,47,28 \& 12 \mathrm{KDa}$. Prolongation the treatment time to $48 \mathrm{hrs}$ the common band disappearance recorded at molecular weight 195,108 KDa. and common band appearance recorded at molecular weight $28 \& 12 \mathrm{KDa}$

In brief treatment with garlic products in each form stimulated some genes to be switch on and successfully translated into new protein, e.g. protein at $\mathrm{Mw} 12 \mathrm{KDa}$ formed under the effect of different concentration of three garlic forms (fresh garlic cloves, garlic tablets and garlic powder) at 24 and 48 hours. The protein at Mw $23 \mathrm{KDa}$ formed under the effect of different concentration of two garlic forms (fresh garlic cloves and garlic tablets) at 24 and 48 hours. 
Table 3: Effect of different garlic forms on protein electrophoresis patterns of Vicia faba (Giza 716) as plant model system.

\begin{tabular}{|c|c|c|c|c|c|c|c|c|c|c|c|c|c|c|}
\hline \multirow{3}{*}{ No } & \multirow{3}{*}{ MW } & \multirow{3}{*}{1} & \multicolumn{2}{|c|}{24 hour } & \multicolumn{2}{|c|}{48 hour } & \multicolumn{2}{|c|}{24 hour } & \multicolumn{2}{|c|}{48 hour } & \multicolumn{2}{|c|}{24 hour } & \multicolumn{2}{|c|}{48 hour } \\
\hline & & & $4.5 \mathrm{~g} / \mathrm{L}$ & $7.11 \mathrm{~g} / \mathrm{L}$ & $4.5 \mathrm{~g} / \mathrm{L}$ & $7.11 \mathrm{~g} / \mathrm{L}$ & 2 tab & 3 tab & 2 tab & 3 tab & $400 \mathrm{mg} / \mathrm{L}$ & $600 \mathrm{mg} / \mathrm{L}$ & $400 \mathrm{mg} / \mathrm{L}$ & $600 \mathrm{mg} / \mathrm{L}$ \\
\hline & & & 2 & 3 & 4 & 5 & 6 & 7 & 8 & 9 & 10 & 11 & 12 & 13 \\
\hline 1 & 270 & - & - & - & - & - & - & - & - & - & + & + & - & - \\
\hline 2 & 195 & + & + & + & + & + & - & - & - & - & + & + & - & - \\
\hline 3 & 180 & + & + & + & + & + & + & + & + & + & + & + & + & + \\
\hline 5 & 150 & - & - & - & - & - & - & - & - & - & + & + & - & - \\
\hline 6 & 140 & - & - & - & - & - & - & - & - & - & + & + & - & - \\
\hline 7 & 130 & + & + & + & + & + & + & + & + & + & + & + & + & + \\
\hline 8 & 108 & + & - & - & + & + & + & + & + & - & + & + & - & - \\
\hline 9 & 95 & + & + & + & + & - & - & - & - & - & + & + & - & + \\
\hline 10 & 90 & - & - & - & - & + & + & - & - & - & - & - & + & - \\
\hline 11 & 85 & + & + & - & + & + & + & + & + & + & + & + & - & + \\
\hline 12 & 77 & - & - & - & - & + & + & + & + & + & - & - & - & + \\
\hline 13 & 70 & + & + & + & + & + & + & + & + & + & + & + & + & + \\
\hline 14 & 65 & + & - & - & + & + & + & + & + & + & + & + & + & - \\
\hline 15 & 56 & + & + & + & + & + & + & + & + & + & - & - & - & + \\
\hline 16 & 51 & + & + & + & + & + & + & + & + & + & + & + & + & + \\
\hline 17 & 49 & + & - & + & + & + & + & + & + & + & - & - & - & + \\
\hline 18 & 47 & - & - & - & - & - & - & - & - & - & + & + & + & - \\
\hline 19 & 44 & - & - & - & - & - & + & - & - & - & + & - & - & - \\
\hline 20 & 42 & + & + & + & + & + & + & + & + & + & + & + & + & + \\
\hline 21 & 40 & + & + & + & + & + & + & + & + & + & + & + & + & + \\
\hline 22 & 36 & ++ & ++ & ++ & ++ & ++ & ++ & ++ & ++ & ++ & ++ & ++ & ++ & ++ \\
\hline 23 & 32 & - & - & - & - & + & + & + & - & - & - & - & - & - \\
\hline 24 & 30 & + & + & + & + & + & + & + & - & + & - & + & + & + \\
\hline 25 & 28 & - & - & - & + & + & + & + & + & + & + & + & + & + \\
\hline 26 & 27 & + & + & + & + & + & + & + & + & + & + & + & + & + \\
\hline 27 & 26 & - & - & - & - & + & + & + & - & - & - & - & - & - \\
\hline 28 & 25 & - & - & - & - & - & - & + & + & + & - & - & - & - \\
\hline 29 & 24 & + & + & + & + & + & + & + & + & + & + & + & + & + \\
\hline 30 & 23 & - & + & + & + & + & + & + & + & + & - & - & - & - \\
\hline 31 & 22 & + & + & + & + & + & + & + & + & + & + & + & + & + \\
\hline 32 & 21 & + & + & - & + & + & + & + & + & + & + & - & + & - \\
\hline 33 & 20 & + & + & + & + & + & + & + & + & + & + & + & + & + \\
\hline 34 & 19 & + & + & + & + & + & + & + & + & + & + & + & + & + \\
\hline 35 & 18 & + & + & - & + & + & + & + & + & + & + & + & + & - \\
\hline 36 & 17 & + & + & + & - & - & - & + & + & + & + & - & + & - \\
\hline 37 & 16 & - & - & - & - & + & + & - & - & - & - & - & - & + \\
\hline 38 & 15 & + & + & + & + & + & + & + & + & + & + & + & + & + \\
\hline 39 & 12 & - & + & + & + & + & + & + & + & + & + & + & + & + \\
\hline \multicolumn{2}{|c|}{ Total } & 24 & 23 & 21 & 26 & 30 & 30 & 29 & 26 & 26 & 28 & 26 & 22 & 22 \\
\hline
\end{tabular}

\section{Discussion}

Regarding the mitotic index as a parameter for the cytotoxicity and used as an indicators of adequate cell proliferation [18] and the percentage of abnormal mitosis as a parameter for the genotoxic effects of the tested materials; the cytogenetic investigations of 2500-3000 cells from three replicates were carried out in order to configure the real effects of the garlic plant product in its three tested forms.

Cytogenetic investigations show that, the reduction in the mitotic index after treatments were concentration and time dependent and reflect the cytotoxic effect of the garlic fresh cloves followed by the garlic powder then tomix tablets came the last; as it show the least reduction in the mitotic index. The slight improvement in the mitotic indexes recorded after $48 \mathrm{~h}$ treatment with the higher concentration of Garlic in the tested forms (3cruched Tomix tablets, 600mg Garlic powder) reveals that the investigated plants under may have adapted the treatment or the $48 \mathrm{hr}$ aged Garlic product have lost some of its volatile components and did not show its assumed effect as $24 \mathrm{hr}$ aged Garlic form did (Table 2).

Concentration-dependent cytotoxicity of garlic product on plant cell was previously obtained by Sadaqa, et al. [19] when investigate the cytological effects of garlic aqueous extract on root tip cells of A. cepa. and also obtained by Suhasini, et al. [20] when tested on animal cells as it approved to reduce in mitotic index, induce growth arrest and morphological differentiation of MCF7 breast cancer cells.

The decrease mitotic index could be attributed to many reasons; it may be due to the alteration of DNA synthesis [21], blocking of the mitotic cycle during G2 [22], time consuming by repairing the damaged DNA at the check point after which the cell-cycle brakes are released and progress resumes [23], inhibition of protein synthesis [24] or the formation of various metabolites necessary for normal sequence of mitosis [25]. 


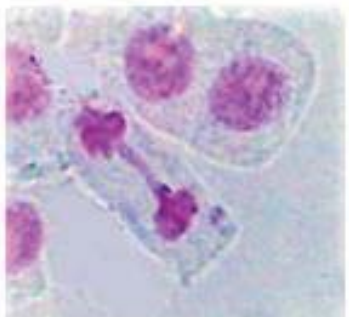

Figure 2

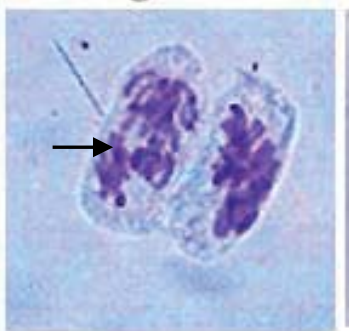

Figure 6

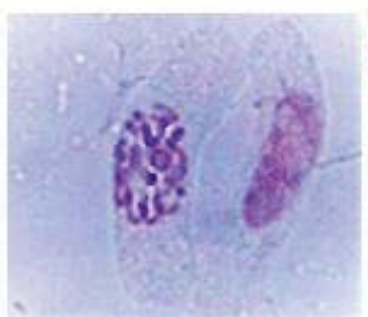

Figure 3

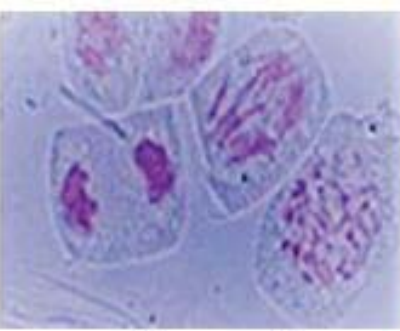

Figure 7

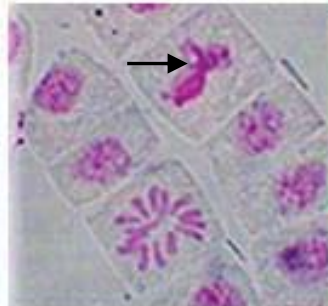

Figure 4

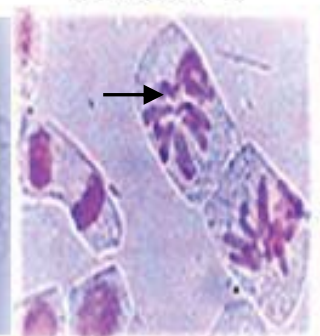

Figure 8

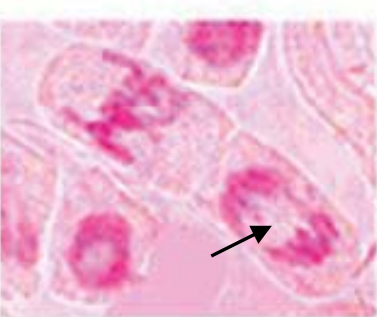

Figure 5

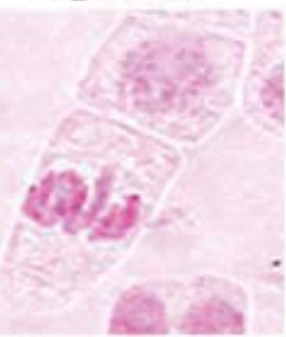

Figure 9

Figure 2-9: Sticky anaphase with sticky bridge after treatment with three mashed Garlic cloves past for 48hr (Figure 2), Pro-metaphase with ring chromosome after treatment with three mashed Garlic cloves past for $48 \mathrm{hr}$ (Figure 3), Sticky metaphase; C- metaphase after treatment with 400mg of Garlic powder foe 24hr (Figure 4), anaphase with broken structural bridge after treatment with three tomix tablets for 24hr (Figure 5), disturbed anaphase (arrow) \& sticky metaphase after treatment with $600 \mathrm{mg}$ of garlic powder for $48 \mathrm{hr}$ (Figure 6) Sticky anaphase \& disturbed anaphase after treatment with two tomix tablets for 48hr (Figure 7), sticky anaphase; disturbed metaphase (arrow) \& sticky anaphase after treatment with two tablets of tomix powder for $24 \mathrm{hr}$ (Figure 8) and clumped metaphase after treatment with $600 \mathrm{mg}$ og garlic powder for $24 \mathrm{hr}$ (Figure 9).

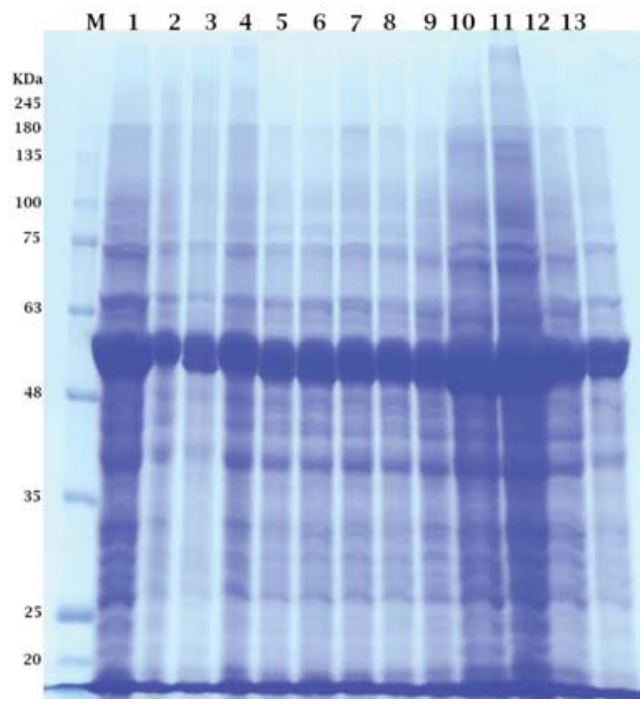

Figure 10: SDS-PAGE total proteins of Vicia faba seedlings pre-treated with different garlic forms.

$M$ is the molecular weight protein marker.

1: Control. 2: $4.5 \mathrm{~g} / \mathrm{L}$ fresh garlic after $24 \mathrm{hrs}$. 3: $7.11 \mathrm{~g} / \mathrm{L}$ fresh garlic after $24 \mathrm{hrs} .4$ : 4.5g/L fresh garlic after $48 \mathrm{hrs} .5: 7.11 \mathrm{~g} / \mathrm{L}$ fresh garlic after $48 \mathrm{hrs} .6: 2$ tabs of tomix after 24 hrs. 7: 3 tabs of tomix after 24 hrs. 8: 2 tabs of tomix after 48 hrs. 9: 3 tabs of tomix after 48 hrs. 10: $400 \mathrm{mg} / \mathrm{L}$ garlic powder after $24 \mathrm{hrs}$. 11: $600 \mathrm{mg} / \mathrm{L}$ garlic powder after 24 hrs. 12: $400 \mathrm{mg} / \mathrm{L}$ garlic powder after 48 hrs. 13: $600 \mathrm{mg} / \mathrm{L}$ garlic powder after $48 \mathrm{hrs}$.

This work also regarded the changes in duration of mitotic phases as an indicator for cytotoxic influence of the materials under investigations. Data revealed that garlic products affected notable change in the frequency of mitotic phases, mostly at prophase stage, as all forms prolong the prophase stages relative to control. Prolongation of prohases may be explained by that; the tested materials in some way block of the dividing cells prevent prophase-metaphase transition as a result of chromosomes condensation delay or the incomplete breakdown of the nuclear envelope or it may affects the chromosomes alignment on the equatorial plate or affect the spindle mechanism [26]. On the other hand treatment with three crushed tomix tablets induced the highest effect on metaphase frequencies, and $24 \mathrm{hr}$ of $400 \mathrm{mg}$ garlic powder induced the highest effect on Ana-telophase duration, this prolongation of metaphases and ana-telophases may be explained by the difficulty in the separation of chromosomes into two chromatids, or could be resulted from the lengthening of their duration that leads to their accumulation ( [27].

Regarding the chromosomal aberrations as an indicator to the mutagenic effect of the tested materials on chromosomes, all the concentration treatments in each of the Garlic forms induced, highly significant increasing percentages of abnormal dividing cell of Vicia faba root meristems. The chromosomal aberrations were found to be concentration and time dependent most of the time with only exception after treatment with 7.11g/ liter of Garlic cloves aqueous extract for $48 \mathrm{hr}$ as it induced lower percentage than expected which may be explained by that Garlic in this form and concentration has increased the mitotic index by the way it could mask its mutagenic effect.

The cytotoxic effect of the $24 \mathrm{hr}$ treatment with three crushed tomix tablets followed by the $7.11 \mathrm{~g} /$ liter of Garlic cloves aqueous extract was accompanied by the mutagenic effect as it produced the highest percentage of abnormal mitosis (37.8 $\$ 35.4 \%$ ) mostly of chromatin material liquefaction, that was also empathized in case of three smashed garlic gloves by 
protein electrophoresis of treated plant leaves as it produces the lower number of recorded protein bands, three protein bands were completely disappeared which may be explained by that; the sever stickiness of chromatin prevent many genes from express themselves through transcription and translation into protein.

On the level of treatment for $48 \mathrm{hrs}$; $400 \mathrm{mg}$ of Garlic powder scored the lowest mitotic index $4.3 \%$ and highest percentage of abnormal mitosis $46.6 \%$ mostly of chromatin liquefaction type, moreover it shows protein bands disappearance in proteins profile.

Regarding the structural aberration and micronucleus as an indicator for the clastogenecity, $24 \mathrm{hrs}$ treatment with Garlic fresh raw \& Garlic powder did not show any effect on chromosomes structure despite the low percentage was scored in control and after treatment with Tomix tablets in its two concentrations; which may explained by that the chromotoxic effect of fresh cloves and garlic powder was sever as they prevent the fragments or breakage from complete separation from the chromosome or may explained by the corrective effect of these two form on the genetic material as Garlic described as an anticancer folk medicin [20]. Prolongation the time of treatment to $48 \mathrm{hr}$; clarify the clastogenecty of the garlic fresh cloves. This clastogenecity effect was emphasized by the results obtained after the leaves' total protein electrophoresis as it was found $24 \mathrm{hr}$ treatment with Garlic fresh raw in its two concentrations and the Garlic powder $600 \mathrm{mg}$ showed the higher number of disappeared bands, while $48 \mathrm{hr}$ treatment with Garlic powder in its two concentrations and tomix were the forms which showed the higher band disappearance.

Regarding the change in the protein profile as an indicator for the potential mutagenic effect of the tested materials on the plant cell: the appearance of new protein bands, the highest number bands recorded after; three smashed cloves for $48 \mathrm{~h}$ and treatment with two crushed tomix tablets for $24 \mathrm{~h}$; this can be explained by mutational event at the regulatory system of unexpected gene(s) that activate it or synthesis of new protein controlled by function genes and /or it might be related to defense responses in the plants to protect themselves from harmful effect of the tested material [28-32].

Despite that treatment with the aqueous extract of three fresh cloves for $24 \mathrm{hr}$ showed mutagenic effect but not of clastogenic type, it showed the highly protein bands disappearance; so this disappearance can be attributed to the chromotoxic effect of the fresh cloves which prevent many genes from get expressed; rather than the clastogenic effect which reflect the genes loss via chromosomes breakage, fragmentation or laggard.

\section{Conclusion}

This study revealed that treatment with different concentration of garlic fresh cloves aqueous extract, and garlic powder in water for $24 \& 48 \mathrm{hr}$ affected the mitotic activities of merestimatic cells. It also revealed that prolonging the time of treatment increases the risk of obtaining micronucleus, which is a countable indicator for the clasto-genecity of the tested product.
On the same track these products affected the total protein profile of Vicia faba seedling leaves. Therefore, it can be concluded that the usage of Garlic extracts as a raw fresh product or as powder in agriculture as fungi-pesticides, should be with caution, as they have been indicated to be mutagenic and cytotoxic on Vicia faba plant.

\section{References}

1. Adam ZM, Mikhael E, El- Ashry ZM, Ehsan NO, Ali RT (2008) Cytogenetics and biochemical studies on Vicia faba plants treated with two insecticidal active plant extract. JGEB 6: 19-27. Link: https://bit.ly/35RBNFj

2. Adam ZM, Mikhael E, El- Ashry ZM, Ehsan NO, Ali RT (2014). Comparative Cytogenetic and Ultra-Structural Effects of Storing Dusted Seeds of Vicia faba with the Insecticide "Malathion 1\%" and Two Insecticidal Active Plant Products. World Applied Sciences Journal 32: 1423-1436. Link: https://bit.ly/35Q7sXG

3. Zaker M (2016) Natural Plant Products as Eco-friendly Fungicides for Plant Diseases Control-A Review. Agriculturists 14: 134-141. Link: https://bit.ly/3pQcyLq

4. Slusarenko AJ, Patel A, Portz D (2008) Control of plant diseases by natural products: Allicin from garlic as a case study. Eur J Plant Pathol 121: 313-322. Link: https://bit.ly/391oHqS

5. Borlinghaus J, Albrecht F, Gruhlke MC, Nwachukwu, ID, Slusarenko AJ (2014) Allicin: Chemistry and Biological Properties. Molecules 19: 12591-12618. Link: https://bit.ly/36Z32Nk

6. Singh VK, Singh DK (2008) Pharmacological Effects of Garlic (Allium sativum L.). Annual Review of Biomedical Sciences 10: 6-26. Link: https://bit.ly/2HmgzWB

7. Reddy KRN, Nurdijati SB, Salleh B (2010) An overview of plant-derived products on control of mycotoxigenic fungi and mycotoxins. Asian J Plant Sci 9: 126133. Link: https://bit.ly/36URKKe

8. Tagoe D, Baidoo S, Dadzie I, Kangah V, Nyarko H (2011) A comparison of the antimicrobial (Antifungal) properties of onion (Allium cepa), Ginger (Zingiber officinale) and garlic (Allium sativum) on Aspergillus flavus, Aspergillus nigerand Cladosporium herbarum using organic and water base extraction methods. Res J Med Plant 5: 281-287. Link: https://bit.ly/2UOqNSE

9. Garlic extract Literature review (2015) Solufeed Ltd. Link: https://bit.ly/2UJbdrE

10. Miron T, Rabinkov A, Mirelman D, Wilchek M, Weiner L (2000) The mode of action of allicin: Its ready permeability through phospholipid membranes may contribute to its biological activity. Biochim Biophys Acta 1463: 20-30. Link: https://bit.ly/3IT147s

11. Rabinkov A, Miron T, Mirelman D, Wilchek M, Glozman S, et al. (2000) S-Allylmercaptoglutathione: The reaction product of allicin with glutathione possesses SH-modifying and antioxidant properties. Biochim Biophys Acta 1499: 144-153. Link: https://bit.ly/35QtsIm

12. Wallock-Richards D, Doherty CJ, Doherty L, Clarke DJ, Place M, et al. (2014) Garlic Revisited: Antimicrobial Activity of Allicin-Containing Garlic Extracts against Burkholderia cepaciaComplex. PLoS One9: e112726. Link: https://bit.ly/35QAaHP

13. Wills ED (1956) Enzyme Inhibition by Allicin, the Active Principle of Garlic. Biochem J 63: 514-520. Link: https://bit.ly/3IXuuSg

14. Ali RT, Abdel-Ghany EM, Mohamed FI, Hanna EM, Elashery ZM (2019) Usage of the cyto-genetics and cytology to identify the action mechanisms of two biofertilizers on Allium cepa meristematic cells. Bulletin of the National Research Centre 43: 138. Link: https://bit.ly/3pl80Xs 
15. Sharma AK, Sharma A (1980) Chromosome Techniques Theory and Practice.3rd . ed. Butterworth and Co. Publishers Itd. 145-150.

16. Laemmli UK (1970) Cleavage of structural proteins during the assembly of the head of bacteriophage T4. Nature 227: 680-685. Link: https://bit.ly/35Smzjw

17. Tsugama D, Liu S, Takano T (2011) A rapid chemical method for lysing Arabidopsis cells for protein analysis. Plant Methods 7: 22. Link: https://bit.ly/3filsg1

18. Gadano A Gurni A, López P, Ferraro G, Carballo ML (2002) In vitro genotoxic evaluation of the medicinal plant Chenopodium ambrosioides. $J$ Ethnopharmacol 81: 11-16. Link: https://bit.ly/330cwXJ

19. Sadaqa EAA, Mohammed SS, Qari SH, Ali KS (2016) Genotoxic Effect of Garlic Extract on Root Tips of Allium Cepa L. Journal of Pharmacy and Biological Sciences 11: 41-44. Link: https://bit.ly/36UwR1H

20. Suhasini M,Stephen ED, Thipparthi RR (2012) Fresh Garlic Extract Induces Growth Arrest and Morphological Differentiation of MCF7 Breast Cancer Cells. Genes Cancer 3: 177-186. Link: https://bit.ly/2KuRgmz

21. Beu SL, Schwarz OJ, Hughes KW (1976) Studies of the herbicide paraquate I-Effect on cell cycle and DNA synthesis in Vicia Faba. Can J Genet Cytol 18 93-99. Link: https://bit.ly/3kMvDKJ

22. Harrison JC, Haber JE (2006) Surviving the breakup: the DNA damage checkpoint. Ann Rev Genet 40: 209-235. Link: https://bit.ly/3fi35b5

23. Hartwell LH, Weinert TA (1989) Checkpoints: control that ensure the order of cell cycle events. Sci 246: 629-634. Link: https://bit.ly/3nGMZus
24. Kim JC, Bendixen EL (1987) Effect of haloxyfop and CGA -82725 on cell cycle and cell division of oat Avene sativa root-tips. Weed Sci 35: 769-774.

25. Amine A (1991) Cytogenetic impact of the molluscicide bayluscide on plants. Ph. D. Thesis, Fac. of Sci., Alexandria Univ., Egypt.

26. Scolnick D, Halazonetis $\mathrm{T}$ (2000) Chfr defines a mitotic stress checkpoint that delays entry into metaphase. Nature 406: 430-435. Link: https://bit.ly/336bnxQ

27. Abdel-Salam AZE, Soliman KhA, Hassan HZ (1997) The mutagenic potentialities of two organophosphorus compounds using different biological systems. Egypt. J Genet Cytol 26: 19-21.

28. Mekki $L$ (2008) The effect of three agricultural chemicals on mitotic division and total seed protein banding profiles of alfalfa (Vicia faba). Int $\mathrm{J}$ Agric Boil 10: 499-504. Link: https://bit.ly/3IRZkvo

29. Adam ZM, Mikhael E, El- Ashry ZM, Ehsan NO, Ali RT (2017) Potentia mutagenic effect of dusting Vicia faba seeds with Malathion1\%powder or fumigating by Phosphine for storage. African J Biol Sci 13: 23-44.

30. Ferreira-Machado SC, Rodrigues MP, Nunes APM (2004) Genotoxic potentiality of aqueous extract prepared from Chrysobalanus icaco L. leaves. Toxicol Lett 151: 481-487. Link: https://bit.ly/3fi2Dtr

31. ISU Extension and Outreach and North Central IPM Center for financia support; guide flyer. Link: https://bit.ly/392IQgd

32. Li Y, Li S, Meng X, Gan RY, Zhang JJ, et al. (2017) Dietary natural products for prevention and treatment of breast cancer. Nutrients 9: 728. Link: https://bit.ly/35MPIls
Discover a bigger Impact and Visibility of your article publication with

Peertechz Publications
Highlights

* Signatory publisher of ORCID

- Signatory Publisher of DORA (San Francisco Declaration on Research Assessment)

- Articles archived in worlds' renowned service providers such as Portico, CNKI, AGRIS, TDNet, Base (Bielefeld University Library), CrossRef, Scilit, J-Gate etc.

* Journals indexed in ICMJE, SHERPA/ROMEO, Google Scholar etc.

- OAI-PMH (Open Archives Initiative Protocol for Metadata Harvesting)

* Dedicated Editorial Board for every journa

* Accurate and rapid peer-review process

* Increased citations of published articles through promotions

- Reduced timeline for article publication

Submit your articles and experience a new surge in publication services (https://www.peertechz.com/submission). 